\title{
full on riot
}

\section{Moses Iten}

'16/02/04 02:42am: hey moses full on riot in lawson st the station's on fire! been going since 4. molotov and more. full on.'

This is the first SMS I have ever received informing me of riots and Molotov cocktails. All this is happening in front of the house I had lived in, until a few weeks ago, before returning to Tasmania. Apparently my old local train station there is on fire. I'm trying to imagine my ex-flatmate tapping this into his phone. full on. I imagine the people I had lived beside - saw daily - throwing burning bottles stuffed with petrol-soaked rags. I doubt anybody is asking why? I don't want to see the 'news' once off this bus. I don't know what to think. Switch off my mobile and put it in my bag on the bus seat beside me.

'What a bastard, this white man, who likes neither my voice nor my colour, yet wants me to come up with a miracle that will make him a god. I shouldn't have got myself into this, but...what can you do? When you're black, no one asks you how you want your own life to be led,' writes B. Wongar - a Serbian-born writer who apparently adopted this name whilst living with an Aboriginal family in the Northern Territory - in 'Girigiri, The Trap.' 
This is from a story about the last man of a tribe condemned to die on a small island, employed by a whitefella who arrives weekly by helicopter for him, to prospect uranium with a Geiger counter. The Aboriginal man is dependent on the food handout, as local food sources have been contaminated by the mining. But his wife has destroyed the counter and, anyhow, there is no uranium on the island: 'There's not a single stone on the island like those of the mainland hills that the whites blasted and dragged away; every Gunavidji man could tell you that, but all of them have gone to Bralgu and I'm the only one left.'

Sitting on a bus from tranquil rural to chilled urban Tasmania, I am reading The Track to Bralgu. Bralgu being both the word for the edible 'yams' and 'mythological island, land of the dead', according to author B. Wongar's glossary. The track, therefore, a matter of both life and death. On the back of the book a critic from the 'Spectator' promises: 'these stories are poignant, deeply committed, plangently mourning the genocide by rapacious white capitalism of a people more deeply in touch with the earth they inhabit than most of us'. On a more sombre note, Thomas Keneally also commends the short story collection as 'arresting chants', and Alan Paton admits 'these beautiful stories open up a new world for me.' These stories come from a book set, printed and bound in Great Britain.

The beauty in the stories lies in both the adversity and the sense of belonging to a community of other human beings and the greater natural world. The reality portrays these same people as the 'victims' of 'rapacious white capitalism'. It is depressing, and whilst I begin enjoying such stories I am exhausted by the reality portrayed; of incessant victimisation.

Horrible stories, I feel. An unresolved conflict that will meander on through history, until the last trickle of Aboriginal life dries up in the desert. As if the first inhabitants of this continent only ever settled remote deserts and tropics, coincidentally the leastfavoured climes for the fresh arrivals from the north. Horrible, I feel, because so often Indigenous Australia is portrayed in this light in a literature aiming to 'preserve' and 'raise awareness' of an ancient culture, but has been more effective in doing the 
opposite by relegating the people in the stories to the shelves of history, the glass cases of museums. Horrible, I feel, but I don't know what to think.

Metallic scraping resonates, increasing to such intensity you want to turn off the stereo spitting it out...spitting out words...English buccaneers...miseries whites inflicted upon blacks...denials...land grabs...massacres...the lot...

'She died on the $8^{\text {th }}$ of May, of 1876, in Hobart. And her one desire was that she should not be given over to the surgeons to dissect her, the way they had cut up King Billy. She wanted to be buried at sea. But the white Tasmanians had other plans for her: they boiled her body down, cleaned down the bones, wired them together and stuck them in a glass case at the Hobart Museum,' explains a voice cutting through the metallic resonance, smoothing the creases in the track The Truth About Tasmania by Curse Ov Dialect. I have heard this song, I went to school in Tasmania and learned Truganinni had been the last full-blood Indigenous Tasmanian to die.

The Melbourne boys from Australia’s first hip hop outfit to be signed to a US label Curse Ov Dialect - are in Hobart. They have just toured the US, Europe and Japan. Their music doesn't get much airplay in Australia. Drizzle becomes rain, and we are in the foyer of the Hobart Museum. It is their first trip to Tasmania. There are hundreds of glass cases.

'We have enough sadness in our lives,' a Palestinian woman whispered to her husband in Arabic who was looking to hang up a picture of Palestinian mothers in mourning in their Washington DC home. I hope you've seen some of the PBS documentary series called 'The New Americans' for it may equally be called 'The New Australians'. Is that why it's screened by the Special Broadcasting Service, and not 'Our ABC'? 
The Palestinian husband in that episode is one of America's leading Palestinian civil rights activists, doing speeches at Nader rallies to shouting 'Free Palestine' in street protests. 'I don't see an end to the conflict, so what's the point,' blurts out his wife in her new-found American 'freedom'. 'So you're gonna give up just like that, on your people,' responds the husband, flabbergasted. The wife just got a job taking care of preschoolers in a predominately Jewish neighbourhood, and loves it. The husband can't believe it, muttering the Arabic words 'in the name of Mohammed' under his breath. 'Do you really believe in God?,' the wife ultimately challenges her husband on camera. The man is silent, the camera switches off.

She makes me think, this woman. I feel numb. I want to curl up.

'These snails are not Tasmanian,' says a friend who is just about to complete a $\mathrm{PhD}$ on Tasmanian land snails. He hands the book back to me and I stare at the cover: a black hand full of snail shells is all it looked like to me. 'To be honest I hadn't even noticed the shells,' I reply, smiling, followed by an awkward silent moment. 'Well, that's interesting, thanks. Seeya!'

The book is called The Child of an Ancient People, and has been translated from the French language. The author, Anouar Benmalek, is an Algerian mathematician, living in exile in France. 'To Truganini, who died on 8 May 1876, the last representative of the Aborigines of Tasmania, a people wiped off the surface of the earth by a perfect genocide: its victims forgotten, the murderers free of blame.'

Understandably, this dedication as you open the book didn't go down well in Australian literary circles; least of all - presumably, for I haven't yet seen any critiques from their perspective - with Indigenous Tasmanians, Truganinni’s descendants. So I had asked the snail friend for his opinion, and he made the interesting observation about the inaccurate cover. Showing the black hands (and a blurry body behind it) of other black 
people, yes, but people of a distinct culture, language and climate zone thousands and thousands of miles away from this island.

Today as I look at these notes, I am sitting on a bus on my way to Hobart. I live on a farm, one hour south. In Hobart I have an interview scheduled with Israeli writer Etgar Keret for midday. I'm searching for something that should connect us, make it a great chat. 'Keret is not afraid of anything; his brilliant stories are like the pricking of needles - traumatic and dreamy, melancholy and replete with humour, never superficial and always precise', proclaims the German newspaper 'Die Welt', on the back sleeve of Keret's paperback The Nimrod Flip-Out. My kinda guy I think, and like The Track to Bralgu (although not with Benmalek), I gambled on interesting cover critics and won. But Keret's stories also speak of beauties and beasts, making the reader squirm and chuckle.

'The fact you live in an area where taking a bus and getting home alive is something that is not taken for granted on both sides puts you in a very existential state of mind. Every day, strong and difficult moral and humanistic problems are thrown in your face - questions that you usually can not offer solutions for. All this certainly affects my writing,' says Keret in an interview on the press release. Can't suppress a yawn, it is early morning. A few other passengers are dozing away on their way to work. The bus turns left off the highway and grinds to a halt. 'Good morning,' mumble the new passenger and driver simultaneously. The doors close and on we go.

Keret is not offering solutions, finality is horror. Questions are raised instead of answers handed on a platter. But that's why I like this bloke. I empathise with things being complicated, nothing simple. One of his stories speaks of a heaven only catering for the afterlife of those who have committed suicide. Imagine the implications of this idea in Israel. 
I had once seen myself as a journalist and headed with a recording device to Redfern 'The Block' - the scene of yesterday's riots. In this open wound of Australia's unresolved past (and future) there was a young Jewish-Aussie photographer, Rick, aged barely fifteen, scooting amongst the locals, deftly. The photographs were brilliant slices of life as it is, unlike other photos I've seen in newspapers of local kids throwing rocks at the camera of a provocative photographer. What makes kids throw rocks at the camera, when without a camera you walk by unhindered? But Rick had no photos of rocks being thrown, he looked like just another kid. Moving like a shadow, it took a while for me to notice him, crouching at a fire and focusing his impressive lens on the flames. When I first approached him and asked why he was taking photos at 'The Block', Rick replied, after a moment’s silence: 'I want to be a war correspondent, and this is Australia’s war zone.' Ultimately Rick illustrated some of my articles. For him it was a thrill to be published, but I felt it wasn’t doing his work justice.

Ultimately I stopped writing articles, reverting to stories [how about testimonies instead of stories?] like this one. I have no idea where Rick is today, we lost contact. I don't know if it's important to call yourself 'journalist' or 'writer', because I currently classify myself as neither. When I decided to move to Redfern last year, I had moved beyond my original naïve intentions of 'changing the world' like stopping the flow of water. To progress to just living in a place to write what I feel, swim with and against the current, perceiving with all my senses like a receptor, a human 'Geiger' counter. A prospector spitting on miners.

In the German language section of a King Street shop, I'm prospecting for rare books. In other languages I could often find books that don't exist in English, disposed by someone who only reads English, dumped in the darkest corner. I recognize a spine as the title of a film I had once borrowed from a video store in Mexico. In German, with Spanish subtitles; the cover of the video (like this book I've just found) shows a group of Indigenous Australians dancing in front of a mound of dirt pushed up by a bulldozer. They have stopped mining prospectors from any further digging on a sacred site. The 
title of this Werner Herzog film - and book - is 'Where the green ants dream'. I am yet to meet an Australian who has seen or even heard of this title, although at a University lecture hall we were shown a Herzog film, showing the rapacious Spanish conquistadores doing similar work in South America. The back cover says, orange letters on empty black: 'What would you say, if in Rome we entered the St. Peter's Basilica with bulldozers, and began to dig?'

The cover of The Track to Bralgu on the other hand, shows a naked Indigenous boy running from a bulldozer rapidly coming towards him.

How will I talk to Etgar Keret about Israel? What would I ask him about last night's 'Redfern riots', screamed in headlines by all the newspapers, suddenly finding room for Indigenous Australia on their front pages? As humorous as some of Keret's stories are, they portray a reality of suicide bombing, the military. Stories set in a climate of resilience, yet soaked in a rag of fear and uncertainty. We all know that, are saturated with those headlines from the tumultuous Middle East (Middle? East?).

I click to last night's SMS message again: hey moses full on riot in lawson st the station's on fire! been going since 4. molotov and more. full on. I select Options. They are Erase, Reply, Chat, Edit...I don’t press Ok, take no action and save the message. 